\title{
PTHrP-producing Tumor: Squamous Cell Carcinoma of the Liver Accompanied by Humoral Hypercalcemia of Malignancy, Increased IL-6 and Leukocytosis
}

\author{
Nobuyuki Asanuma, Keisuke Hagiwara, Ikuko Matsumoto, Masahiro Matsuda, Fumiaki Nakamura, Haruhiko \\ Kouhara*, Makoto MiYamoto**, Yoshihiro Miyashita, Sanai Noguchi and Yasuhiko Morimoto
}

\begin{abstract}
A 77-year-old man was admitted to our hospital showing symptoms of general fatigue and appetite loss. He had leukocytosis, thrombocytosis and hypercalcemia with elevated serum levels of parathyroid hormone related peptide (PTHrP) and interleukin-6 (IL-6). An increase in tumor markers SCC and CYFURA21-1 was observed. The liver contained a huge tumor, which was proved to be PTHrP producing squamous cell carcinoma by immuno-histochemical analysis. Since the tumor did not express IL-6, it was assumed to be induced by PTHrP in osteoblasts. This is the first report of PTHrP producing squamous cell carcinoma of the liver.
\end{abstract}

(Internal Medicine 41: 371-376, 2002)

Key words: calcium, parathyroid hormone, cytokine, liver cyst

\section{Introduction}

Parathyroid hormone related peptides (PTHrP) were first identified in 1987. The physiological function of PTHrP is thought to be a local growth factor, but it has not been analyzed closely. Serum PTHrP level in the body is low and not detectable in the physiological state. When cancer cells produce a large amount of PTHrP, serum PTHrP level is elevated. PTHrP then binds to the PTH/PTHrP receptors in both the bone and kidney, which induces intracellular signal transduction, resulting in serum calcium increase. These symptoms are called humoral hypercalcemia of malignancy (HHM) $(1,2)$. Among the many kinds of cancer cells, more than half of HHM is caused by squamous cell carcinomas (3) originating in the lung, skin and alimentary tract. Most of the squamous cells and squamous cell carcinoma express PTHrP (4), but elevated serum concentrations of PTHrP can be detected only in patients with cancer that express high levels of PTHrP. Squamous cell carcinoma of the liver is a very rare disorder, which has been reported only in 18 cases to date. Among them, only one case was associated with hypercalcemia (5). In this paper, we report a case of PTHrP producing squamous cell carcinoma of the liver with HHM, high serum IL-6 level, leukocytosis and thrombocytosis.

\section{Case Report}

A 77-year-old Japanese man was admitted to our hospital in December 1997. He had suffered from general fatigue, appetite loss and body weight loss from $55 \mathrm{~kg}$ to $47 \mathrm{~kg}$ since $\mathrm{Au}-$ gust 1997 . His symptoms had become worse during the previous two months. His family history revealed that his mother had rheumatoid arthritis, but there were no other particular diseases among his relatives. He had cervical spondylosis and had undergone surgery for bilateral cataracts at the age of 76 .

On admission he was generally emaciated, $159 \mathrm{~cm}$ in height, weight $47 \mathrm{~kg}$, and showed signs of cachexia. Blood pressure was $130 / 68 \mathrm{mmHg}$. Icterus and anemia were not observed in his conjunctiva. There were no pathological findings on his skin. Chest sound was vesicular and the heart had no murmurs. His abdomen was flat and no venous dilatation was observed. The liver, spleen, kidney and the tumor, as well, were not palpable.

Laboratory data showed mild anemia, leukocytosis and thrombocytosis (Table 1). Serum calcium level was $16.7 \mathrm{mg} /$ $\mathrm{ml}$ and still high after adjustment by serum albumin level. Liver function tests were within the normal range except for a mild increase in $\gamma$ glutamyl transpeptidase level. Hepatitis $C$ virus antibody was positive, but hepatitis C virus RNA was negative. Increase in C-reactive protein and tumor markers, such as SCC, CYFURA21-1 and neuron-specific enolase (NSE) were observed. These findings suggested that the patient was carry-

From the Department of Internal Medicine, Aizenbashi Hospital, Osaka, the Departments of *Endocrinology and **Pathology, Osaka University Hospital, Osaka

Received for publication August 1, 2001; Accepted for publication December 15, 2001

Reprint requests should be addressed to Dr. Nobuyuki Asanuma, the Department of Molecular Medicine, Osaka University Medical School, 2-15 Yamada-oka, Suita, Osaka 565-0871 
Table 1. Laboratory Data

\begin{tabular}{|c|c|c|c|}
\hline \multicolumn{2}{|c|}{$<$ Complete blood cell count $>$} & \multirow{2}{*}{\multicolumn{2}{|c|}{$\begin{array}{l}<\text { Virus antibody }> \\
\text { Hepatitis } \mathrm{C} \text { virus antibody } \\
\end{array}$}} \\
\hline WBC & $22.0 \times 10^{3} / \mathrm{mm}^{3}$ & & \\
\hline \multicolumn{2}{|c|}{ (Neutrophil 79\%, Lymphocyte 15\% } & \multicolumn{2}{|c|}{ Hepatitis $C$ virus RNA } \\
\hline \multicolumn{2}{|c|}{ Monocyte 5\%, Eosinophil 1\%) } & \multirow{2}{*}{\multicolumn{2}{|c|}{$\begin{array}{l}\text { Hepatitis B virus surface antigen } \\
\text { Hepatitis B virus surface antibody }\end{array}$}} \\
\hline$\underline{\mathrm{RBC}}$ & $369 \times 10^{4} / \mathrm{mm}^{3}$ & & \\
\hline Hemoglobin & $11.1 \mathrm{~g} / \mathrm{dl}$ & \multirow{2}{*}{\multicolumn{2}{|c|}{ Hepatitis B virus core antibody }} \\
\hline Platelet & $41.9 \times 10^{4} / \mathrm{mm}^{3}$ & & \\
\hline \multicolumn{2}{|l|}{$<$ Biochemical data $>$} & \multicolumn{2}{|c|}{$<$ Tumor markers $>$} \\
\hline $\mathrm{Ca}$ & $16.7 \mathrm{mg} / \mathrm{dl}$ & CEA & $2.9 \mathrm{ng} / \mathrm{ml}$ \\
\hline $\mathrm{P}$ & $3.3 \mathrm{mg} / \mathrm{dl}$ & AFP & $3.1 \mathrm{ng} / \mathrm{ml}$ \\
\hline Total-protein & $7.7 \mathrm{~g} / \mathrm{dl}$ & PIVKA II & $35 \mathrm{AU} / \mathrm{ml}$ \\
\hline Albumin & $3.7 \mathrm{~g} / \mathrm{dl}$ & $\underline{\mathrm{SCC}}$ & $9.2 \mathrm{ng} / \mathrm{ml}(\leqq 1.5)$ \\
\hline \multirow[t]{2}{*}{ AST } & $24 \mathrm{IU} / l$ & NSE & $13 \mathrm{ng} / \mathrm{m}(\leqq 10)$ \\
\hline & & CYFURA21 & $37.2 \mathrm{ng} / \mathrm{m}(\leqq 3.5)$ \\
\hline ALT & $15 \mathrm{IU} / l$ & ProGRP & $17 \mathrm{pg} / \mathrm{ml}$ \\
\hline$\gamma \mathrm{GTP}$ & $64 \mathrm{IU} / \mathrm{l}$ & & \\
\hline ALP & $356 \mathrm{IU} / l$ & & \\
\hline LDH & $248 \mathrm{IU} / l$ & \multicolumn{2}{|c|}{$<$ Hormones and cytokines $>$} \\
\hline Total-bilirubin & $0.55 \mathrm{mg} / \mathrm{dl}$ & PTHrP & $333 \mathrm{pmol} / \mathrm{l}(13.8-55.3)$ \\
\hline \multirow[t]{2}{*}{ ZTT } & 11.3 Kunkel Unit & PTH & $<0.6 \mathrm{pmol} / \mathrm{l}(160-520)$ \\
\hline & & Calcitonin & $56.3 \mathrm{pmol} / l(31.9-43.3)$ \\
\hline Choline esterase & $131 \mathrm{IU} / l$ & $\underline{\mathrm{IL}-6}$ & $122.2 \mathrm{pg} / \mathrm{ml}(0.16-7.25)$ \\
\hline Glucose & 103 mg/dl & IL-3 & $<5 \mathrm{pg} / \mathrm{ml}$ \\
\hline Total-cholesterol & 174 mg/dl & G-CSF & $14.0 \mathrm{pg} / \mathrm{ml}$ \\
\hline Triglyceride & $191 \mathrm{mg} / \mathrm{dl}$ & GM-CSF & $3.36 \mathrm{pg} / \mathrm{ml}$ \\
\hline ICG (15 min) & $3 \%$ & & \\
\hline CRP & $11.2 \mathrm{mg} / \mathrm{dl}$ & & \\
\hline Rheumatoid factor & $(-)$ & & \\
\hline Anti-nuclear antibody & $(-)$ & & \\
\hline
\end{tabular}

Underlines indicate abnormal data.

ing squamous cell carcinoma in his body. Endocrinological studies showed an enhanced PTHrP level and suppressed PTH level, which resulted in hypercalcemia. Interleukin-6 (IL-6) level was also elevated. But other cytokines, granulocyte-colony stimulating factor (G-CSF), granulocyte-macrophage-colony stimulating factor (GM-CSF) and interleukin-3 (IL-3) levels were not increased. These findings suggested humoral hypercalcemia of malignancy (HHM).

Chest roentgenography showed that the right diaphragm was elevated (Fig. 1A). Abdominal ultrasonography and computed tomography (CT) revealed the presence of a large tumor in S8 and $\mathrm{S} 7$ regions of the liver. The tumor was irregular and inhomogeneous, $11 \times 10 \mathrm{~cm}$ in size, and poorly enhanced by contrast medium (Fig. 1B). Dome of the liver protruded into the right pleural cavity by mass effect of the tumor.

As there was a possibility that the tumor was metastatic, extensive examinations of skin, head, otorhinolaryngial region, chest, abdomen, and urogenital tract were performed. Gastrointestinal fibers showed evidence of atrophic gastritis but no malignant tumor was detected. Barium enema of the large intestine revealed a sigmoid colon polyp of $7 \mathrm{~mm}$ in diameter. Brain, chest and lower abdominal CT scans were conducted, but no tumor was found in these regions. As bone resorption by the malignant tumor may cause hypercalcemia, systemic bone scintigraphy was performed to survey bone metastatic lesions with no remarkable findings. An otolaryngologist and a urologist examined the patient, but there was no malignant tumor. On the basis of these results, we concluded that the tumor originated in the liver.

On December 3, the patient was diagnosed with humoral hypercalcemia of malignancy. Neither surgical resection of the tumor, nor specific chemotherapy was performed, because his general condition was not good. Palliative care to reduce the serum calcium level was initiated. We first prescribed administration of intramuscular calcitonin, but this drug was not effective. From December 22, intravenous injection of bisphosphonate was performed, and the serum calcium level decreased immediately and was controlled around $10 \mathrm{mg} / \mathrm{ml}$ (Fig. 2, lower). Serum PTHrP concentration gradually increased and reached more than $600 \mathrm{pmol} / l$, which was in parallel with the elevation of the serum CYFURA21-1 level (Fig. 2, middle). These findings suggested that the tumor produced PTHrP and the gradual increase in serum PTHrP concentration had been the result of tumor growth. On the other hand, the serum CRP 


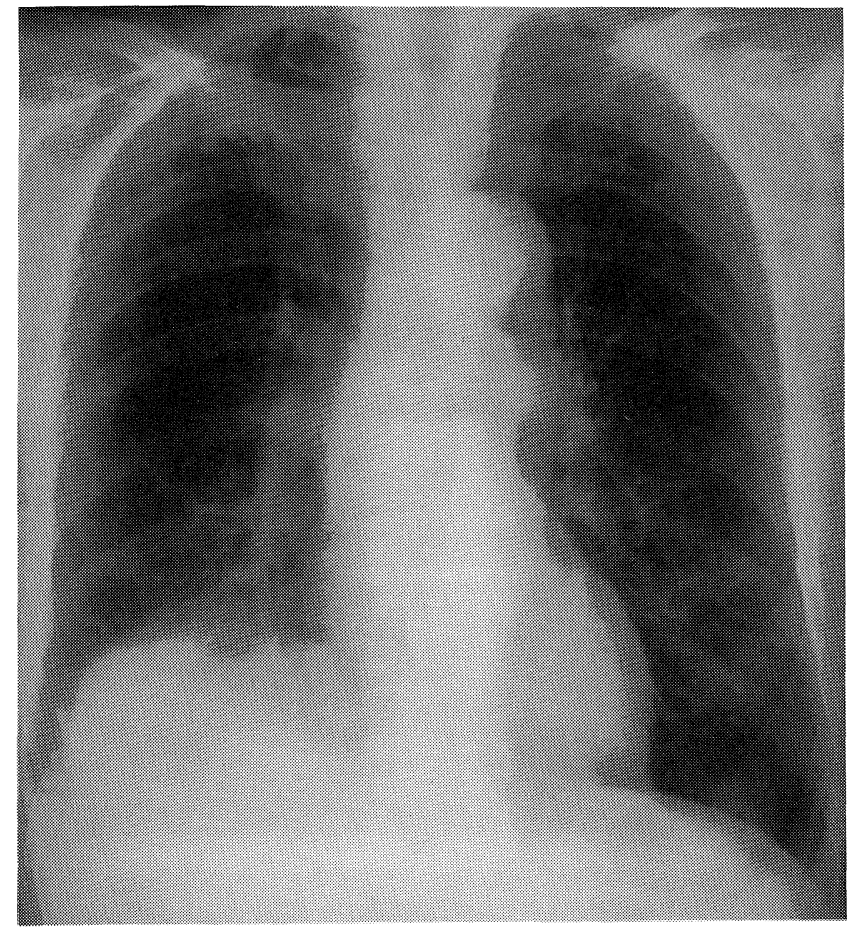

A

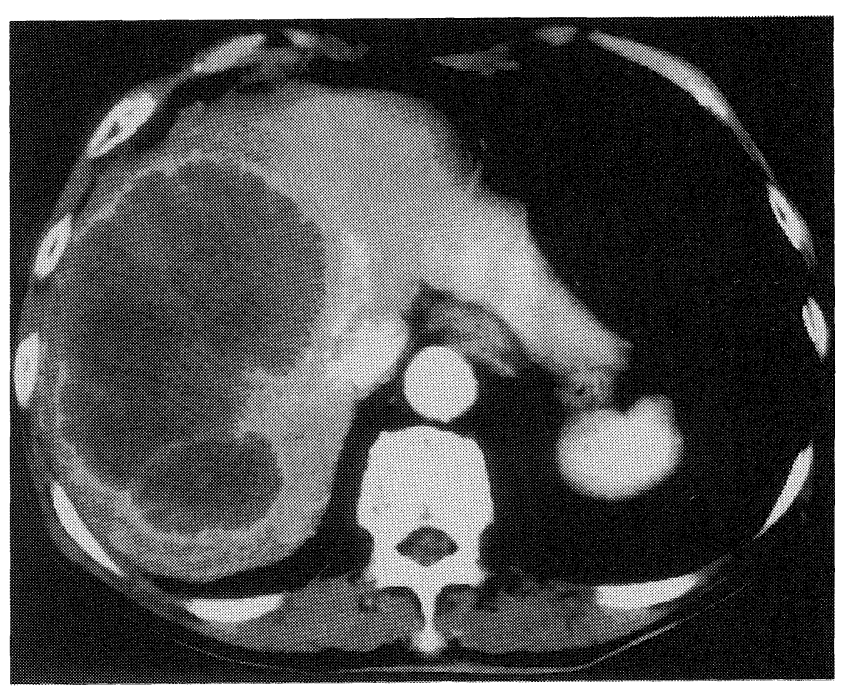

B

Figure 1. Chest X-ray film and abdominal CT. (A) Plain chest X-ray film. The right diaphragm was elevated by the liver tumor. (B) Contrast-enhanced abdominal computed tomography. The large tumor showed low density and a well-circumscribed lesion. It was a solitary tumor on contrast-enhanced computed tomography.

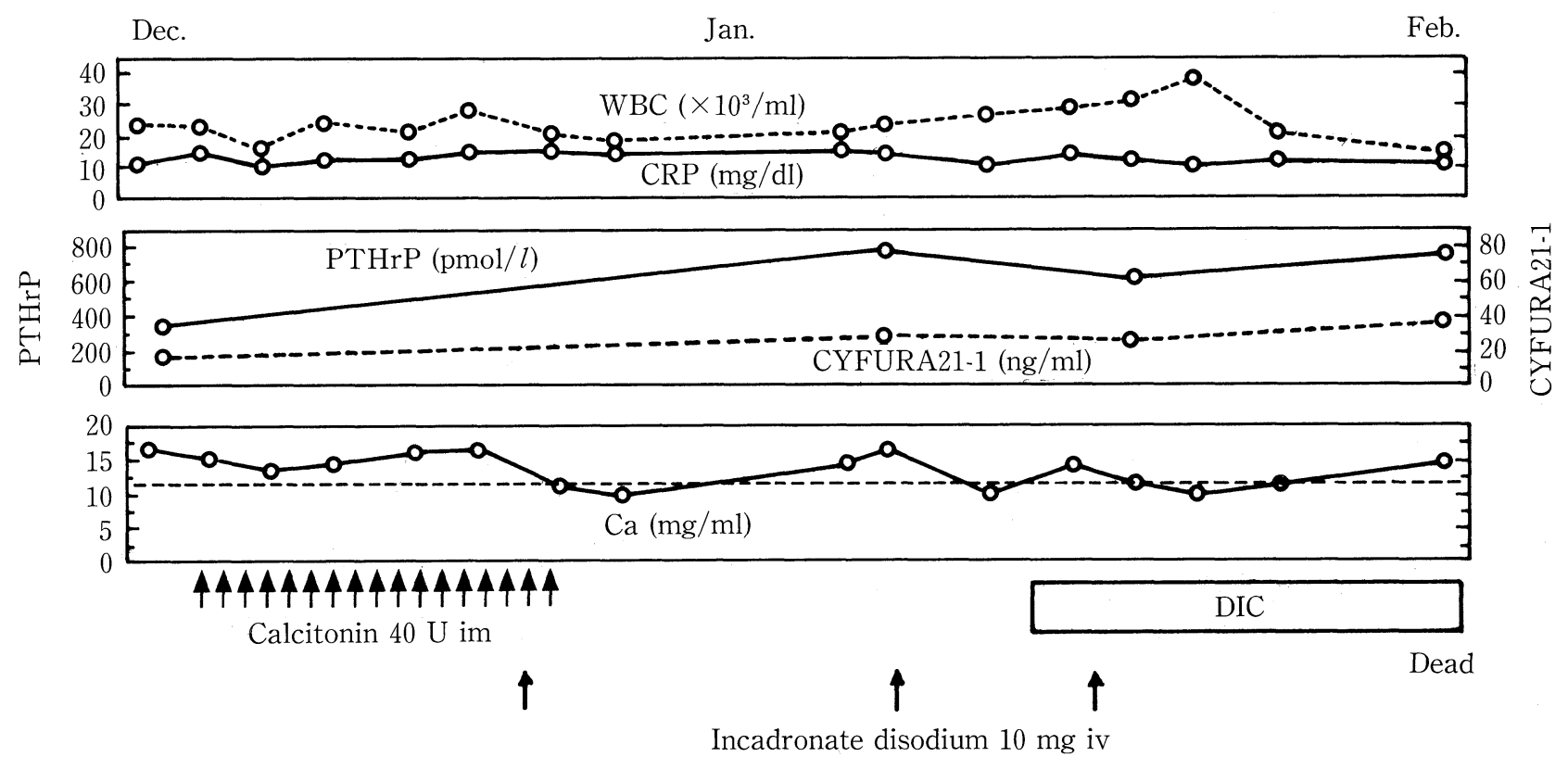

Figure 2. Clinical course. The time courses of WBC, CRP, PTHrP, CYFURA21-1, and Ca are shown. The time courses of the anti-hypercalcemic therapies using calcitonin and incadronate disodium are indicated at the bottom. PTHrP: parathyroid hormone related peptide, Ca: calcium, DIC: disseminated intravascular coagulation. 
concentration remained at a high level despite the fact that no apparent inflammatory disorder could be detected throughout the clinical course (Fig. 2, upper). On January 15, the patient was diagnosed with disseminated intravascular coagulation and died on February 8 because of multiple organ failure. Needle necropsy of the tumor tissue was performed.

Immunohistochemistry of the tumor tissue was conducted. The tumor was positive for keratin (Fig. 3B), and was diag-

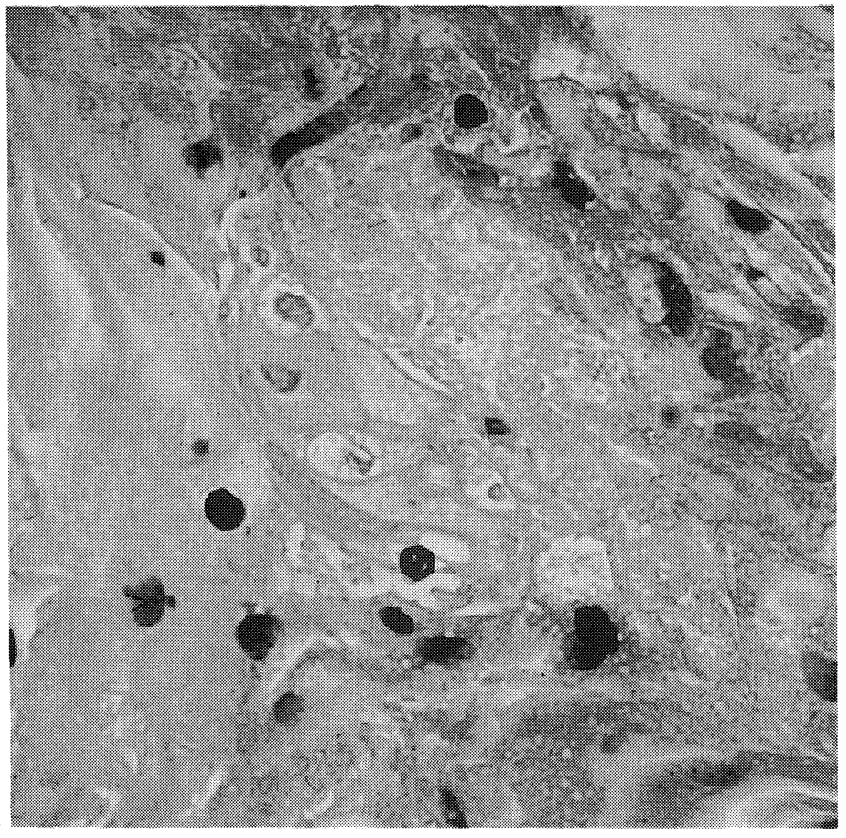

A

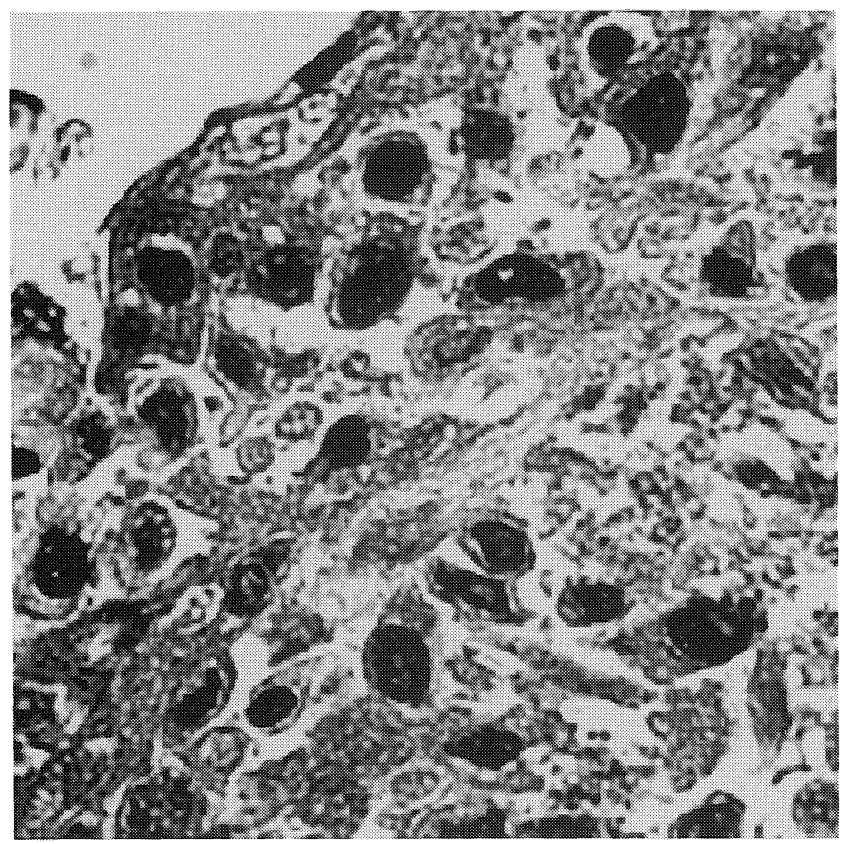

C

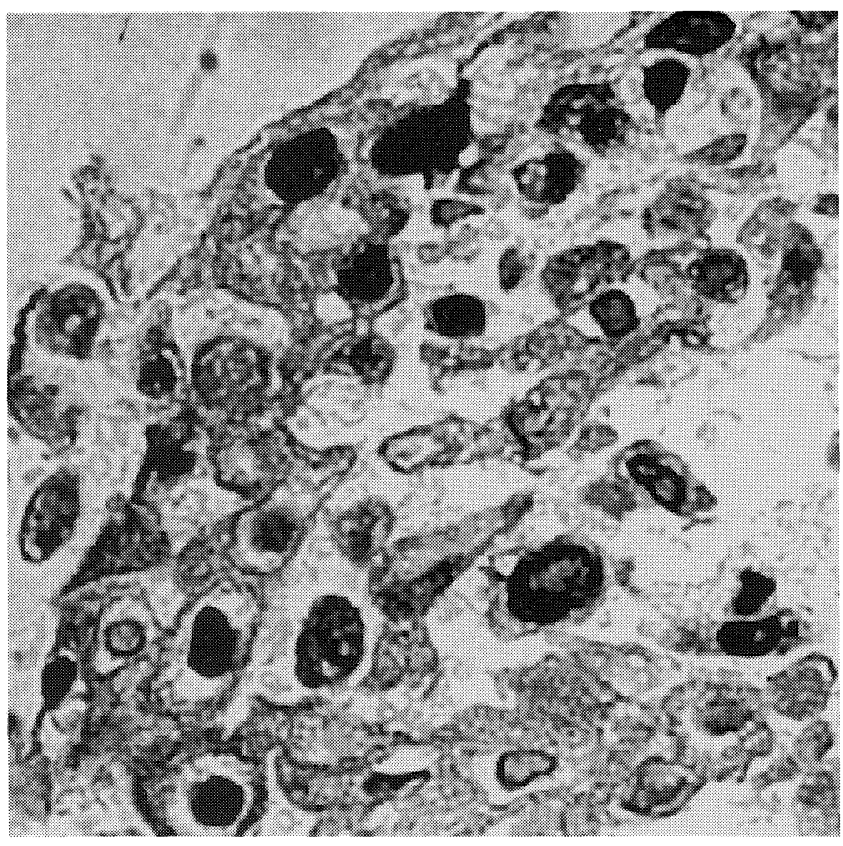

B

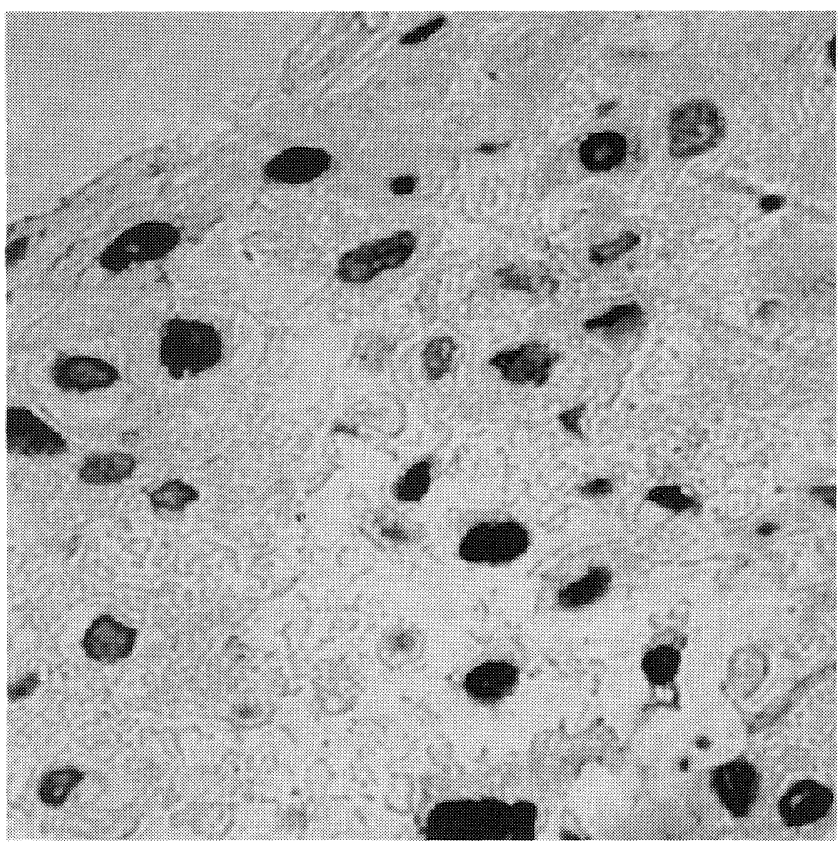

$\mathrm{D}$

Figure 3. Histological analysis of the tumor tissue. Hematoxylin-eosin staining of the necropsied tumor tissue (A, $\times 400)$. The samples were immunostained with anti-keratin antibody $(\mathrm{B}, \times 400)$, anti-PTHrP antibody $(\mathrm{C}, \times 400)$ and anti-IL-6 antibody $(\mathrm{D}$, $\times 400)$. The tumor was squamous cell carcinoma and expressed PTHrP, but did not express IL-6. 
nosed with squamous cell carcinoma with the findings of hematoxylin-eosin staining (Fig. 3A). Because serum IL-6 and PTHrP levels of the patient were elevated, we examined their expression in the tumor cells. The results showed that the tumor cells were positive for PTHrP (Fig. 3C), but did not express IL-6 (Fig. 3D), while alpha-feto protein and G-CSF were not detected by immuno-histochemical analysis of the tumor tissue (data not shown).

\section{Discussion}

Here, we present a case of humoral hypercalcemia of malignancy caused by squamous cell carcinoma of the liver. The incidence rate of this tumor is reported to be about $0.005 \%$ of total autopsies (6). As seen in Table 2, there are only 18 cases, which have been reported in the English or German language literature. This low incidence rate of liver squamous cell carcinoma suggests that the presence of squamous cells is very rare in the liver, and therefore the cancer may have originated in aberrant squamous cells. This hypothesis is supported by the fact that more than half (11/18 cases) of the reported cases are associated with liver cysts (Table 2). In the 18 reported cases, not all tumors were directly associated with cysts. However an intensive search for accompanying cysts may not have been performed in every case, or the original cyst may have become atrophic because of the tumor mass effect. In our clinic, we frequently diagnose liver cysts on ultrasonographs or computed tomographs, and it is possible that the lining cells of the cysts could transform into squamous cell carcinoma. It is hard to say conclusively, as the incidence of squamous cell carcinoma of the liver is extremely low, but some squamous cell carcinomas may have emerged from the squamous cells of the liver cysts.
In the present patient, the serum levels of PTHrP and IL-6 were increased. These two factors were biologically active, because increased serum levels of their downstream effector, calcium and C-reactive protein respectively, had also been observed. This patient also showed leukocytosis and thrombocytosis, but G-CSF, GM-CSF and IL-3 were not enhanced. We cannot explain these phenomena conclusively, but we may assume that leukocytosis and thrombocytosis are downstream effects of IL-6 elevation. The tumor cells proved strongly positive for PTHrP by immunohistochemistry. On the other hand, it was negative for IL-6 and the tumor cells did not produce this cytokine. As no apparent inflammatory disorder was seen in the patient, including his lung and liver, the elevated PTHrP level may have triggered the increase in IL- 6 concentration. In vitro, PTHrP/PTH induced IL-6 expression in osteoblasts (7, 8 ), which was followed by stimulation of osteoclasts and resulted in additional bone resorption (9). IL-6 transmited the signal from osteoblasts to osteoclasts. Those interactions were supported by the fact that, even if serum PTH levels were elevated in IL-6 knockout mice, there was no addition in osteoclastc activity, and blunted osteoclastc activity could be overcome by IL-6 addition (10). This fact was also supported by an overexpressing system. An IL-6 and PTHrP double producing tumor showed higher osteolytic activity than a PTHrP single producer, when the cells were transplanted in nude mouse, while an IL-6 single producing tumor showed weak osteolytic activity (11). These results suggest that IL-6 is located downstream of the PTHrP/PTH signaling pathway, even though the PTHrP/PTH pathway does not fully activate the IL-6 signaling pathway. But clinically, the relation between PTHrP and IL-6 is not so clear. One study reported a correlation between serum PTHrP levels and calcium levels, but no

Table 2. Literature Review of Squamous Cell Carcinomas of the Liver

\begin{tabular}{cccclc}
\hline Patient & Cyst & Metaplasia & \multicolumn{1}{c}{ Others } & \multicolumn{1}{c}{ Authors } & Reference \\
\hline $32 \mathrm{M}$ & - & - & Teratoma & Imai (1934) & 14 \\
$30 \mathrm{M}$ & + & + & & Irwin (1944) & 15 \\
$56 \mathrm{M}$ & + & + & & Edmondson (1958) & 16 \\
$59 \mathrm{M}$ & - & - & & Geddes (1970) & 17 \\
$37 \mathrm{M}$ & + & + & & Greenwood (1972) & 18 \\
$30 \mathrm{M}$ & + & + & & Bloustein (1976) & 19 \\
$38 \mathrm{~F}$ & - & + & Duct metaplasia & Chaudhuri (1982) & 20 \\
$43 \mathrm{M}$ & - & - & Hepatolithiasis & Song (1984) & 21 \\
$78 \mathrm{M}$ & + & + & & Gresham (1985) & 6 \\
$63 \mathrm{M}$ & + & + & & Lynch (1988) & 22 \\
$63 \mathrm{M}$ & - & - & Liver cirrhosis & Arase (1988) & 5 \\
$73 \mathrm{M}$ & - & - & & Clements (1990) & 23 \\
$51 \mathrm{~F}$ & + & - & & Roediger (1991) & 24 \\
$62 \mathrm{~F}$ & + & - & & Nieweg (1992) & 25 \\
$82 \mathrm{~F}$ & + & + & & Pliskin (1992) & 26 \\
$59 \mathrm{~F}$ & + & + & & Banbury (1994) & 27 \\
$74 \mathrm{~F}$ & + & - & Chronic inflammation & Weimann (1996) & 28 \\
$56 \mathrm{~F}$ & - & + & Duct metaplasia & Shinagawa (1996) & 29 \\
$77 \mathrm{M}$ & - & - & & Asanuma (2001) & Present case \\
\hline
\end{tabular}


correlation between IL- 6 levels in patients with cancer and hypercalcemia (12). These findings suggest that the IL-6 signaling pathway is not simply regulated by PTHrP signaling alone. Bone marrow cells produce many inhibitory and stimulatory factors that affect osteoclastic activity (13). Therefore, PTHrP may once induce IL- 6 expression, but downstream, the signaling pathway of IL-6 may be blocked by some factors without altering the serum IL- 6 concentration. As our patient had no apparent inflammatory lesions, the elevated serum IL- 6 concentration was thought to be from the effect of PTHrP on osteoblasts. The IL- 6 concentration correlated well with the serum calcium level, which reflects osteoclastic activities. And these relations could be accurately analyzed when the anti-IL6 receptor antibody was therapeutically prescribed to block this cascade.

\section{References}

1) Broadus AE, Mangin M, Ikeda K, et al. Humoral hypercalcemia of cancer. Identification of a novel parathyroid hormone-like peptide. $\mathrm{N}$ Engl $\mathrm{J}$ Med 319: 556-563, 1988.

2) Grill V, Rankin W, Martin TJ. Parathyroid hormone-related protein (PTHrP) and hypercalcaemia. Eur J Cancer 34: 222-229, 1998.

3) Burtis WJ, Brady TG, Orloff JJ, et al. Immunochemical characterization of circulating parathyroid hormone-related protein in patients with humoral hypercalcemia of cancer. N Engl J Med 322: 1106-1112, 1990.

4) Danks JA, Ebeling PR, Hayman J, et al. Parathyroid hormone-related protein: immunohistochemical localization in cancers and in normal skin. J Bone Miner Res 4: 273-278, 1989.

5) Arase Y, Endo Y, Hara M, Kumada H, Ikeda K, Yoshiba A. Hepatic squamous cell carcinoma with hypercalcemia in liver cirrhosis. Acta Pathol Jpn 38: 643-650, 1988.

6) Gresham GA, Rue LW 3rd. Squamous cell carcinoma of the liver. Hum Pathol 16: 413-416, 1985

7) De Miguel F, Martinez-Fernandez P, Guillen C, et al. Parathyroid hormone-related protein (107-139) stimulates interleukin-6 expression in human osteoblastic cells. J Am Soc Nephrol 10: 796-803, 1999.

8) Onyia JE, Libermann TA, Bidwell J, et al. Parathyroid hormone (1-34)mediated interleukin-6 induction. J Cell Biochem 67: 265-274, 1997.

9) Nagai Y, Yamato H, Akaogi K, et al. Role of interleukin-6 in uncoupling of bone in vivo in a human squamous carcinoma coproducing parathyroid hormone-related peptide and interleukin-6. J Bone Miner Res 13: 664-672, 1998

10) Grey A, Mitnick MA, Masiukiewicz U, et al. A role for interleukin-6 in parathyroid hormone-induced bone resorption in vivo. Endocrinology 140 (10): 4683-4690, 1999.

11) Weissglas MG, Schamhart DH, Lowik CW, Papapoulos SE, Theuns HM, Kurth KH. The role of interleukin- 6 in the induction of hypercalcemia in renal cell carcinoma transplanted into nude mice. Endocrinology 138: 1879-1885, 1997.

12) Motellon JL, Jimenez FJ, de Miguel F, et al. Relationship of plasma bone cytokines with hypercalcemia in cancer patients. Clin Chim Acta 302: $59-68,2000$.

13) Atkins GJ, Haynes DR, Geary SM, Loric M, Crotti TN, Findlay DM. Coordinated cytokine expression by stromal and hematopoietic cells during human osteoclast formation. Bone 26 (6): 653-661, 2000.

14) Imai T. Ein Fall von zystischem Teratom der Leber, in welchen Plattenepithelkrebs entstaud. Trans Soc Pathol Jpn 24: 578-582, 1934 (German).

15) Irwin ST, Morison JE. Congenital cyst of the common bile-duct containing stones and undergoing cancerous change. Br J Surg 32: 319-321, 1944.

16) Edmondson HA. Tumors of the liver and intrahepatic bile ducts. In: Atlas of Tumor Pathology, Section 7, Fascicle 25. Armed Forces Institute of Pathology, Washington DC, 1958: 109-111.

17) Geddes EW. Hepatomegaly due to primary squamous carcinoma. Proc Mine Med Off Assoc 49: 189-191, 1970.

18) Greenwood N, Orr WM. Primary squamous-cell carcinoma arising in a solitary non-parasitic cyst of the liver. J Pathol 107: 145-148, 1972.

19) Bloustein PA, Silverberg SG. Squamous cell carcinoma originating in an hepatic cyst. Case report with a review of the hepatic cyst-carcinoma association. Cancer 38: 2002-2005, 1976.

20) Chaudhuri PK, Chaudhuri B, Schuler JJ, Nyhus LM. Carcinoma associated with congenital cystic dilation of bile ducts. Arch Surg 117: 1349$1351,1982$.

21) Song E, Kew MC, Grieve T, Isaacson C, Myburgh JA. Primary squamous cell carcinoma of the liver occurring in association with hepatolithiasis. Cancer 53: 542-546, 1984

22) Lynch MJ, McLeod MK, Weatherbee L, Gilsdorf JR, Guice KS, Eckhauser FE. Squamous cell cancer of the liver arising from a solitary benign nonparasitic hepatic cyst. Am J Gastroenterol 83: 426-431, 1988.

23) Clements D, Newman P, Etherington R, Lawrie BW, Rhodes J. Squamous carcinoma in the liver. Gut 31: 1333-1334, 1990.

24) Roediger WE, Dymock RB. Primary squamous carcinoma of the liver: clinical and histopathological features. Aust N Z J Surg 61: 720-722, 1991.

25) Nieweg O, Slooff MJ, Grond J. A case of primary squamous cell carcinoma of the liver arising in a solitary cyst. HPB Surg 5: 203-208, 1992.

26) Pliskin A, Cualing H, Stenger RJ. Primary squamous cell carcinoma originating in congenital cysts of the liver. Report of a case and review of the literature. Arch Pathol Lab Med 116: 105-107, 1992.

27) Banbury J, Conlon KC, Ghossein R, Brennan MF. Primary squamous cell carcinoma within a solitary nonparasitic hepatic cyst. J Surg Oncol 57: 210-212, 1994

28) Weimann A, Klempnauer J, Gebel M, et al. Squamous cell carcinoma of the liver originating from a solitary non-parasitic cyst case report and review of the literature. HPB Surg 10: 45-49, 1996.

29) Shinagawa $T$, Tadokoro $M$, Takagi $M$, et al. Primary squamous cell carcinoma of the liver: a case report. Acta Cytol 40: 339-345, 1996. 